\title{
Law and the Human Cost of Social and Economic Development
}

\author{
Eric D. Smaw \\ Department of Philosophy and Religion, Rollins College, Winter Park, USA \\ Email: esmaw@rollins.edu
}

Received 17 May 2016; accepted 19 June 2016; published 22 June 2016

Copyright (C) 2016 by author and Scientific Research Publishing Inc.

This work is licensed under the Creative Commons Attribution International License (CC BY). http://creativecommons.org/licenses/by/4.0/

(c) (i) Open Access

\begin{abstract}
In what follows, I offer philosophical analyses of the history of the United States for the purpose of demonstrating that many industries in America thrived on the enslavement, segregation, oppression, and exploitation of African-Americans. As a way of overcoming the problems of the past, I offer a five-fold solution that entails compensating the victims of oppression and exploitation, repealing the protections that shield those who engage in oppression and exploitation from criminal and civil responsibility, encouraging "whistle-blowers" to come forward and praising them as advocates of social justice when they do so, developing interpersonal relations between those who are oppressed and exploited and social justice advocates, and utilizing social justice advocates to ensure that the principles of liberty and equality, codes of ethics, and anti-discrimination laws are not violated or sacrificed for economic gains or any other reasons. In the end, I conclude with an analysis of how we might reconceive of the relations between businesses, communities, and individuals such that we can engage in social and economic development and avoid oppression and exploitation.
\end{abstract}

\section{Keywords}

Compensatory Justice, Discrimination, Economic Exploitation, Medical Apartheid, Segregation, and Slavery

\section{Introduction}

Never forget that for 250 years black people were born into chains - whole generations followed by more generations who knew nothing but chains. You must struggle to truly remember this past in all its nuance, error, and humanity. You must resist the common urge toward the comforting narrative of divine law, toward fairy tales that imply some irrepressible justice. The enslaved were not bricks in your road, and their 
lives were not chapters in your redemptive history. They were people turned to fuel for the American machine. ${ }^{1}$

Like Ta-Nehisi Coates, I believe that one way we honor the lives of those who suffered under oppression is through remembrance. But we must not simply remember the plights of the oppressed. Rather, we must acknowledge, name, and condemn the egregious human rights violations they suffered in the United States, including dehumanization, disfranchisement, displacement, discrimination, enslavement, forced labor, kidnapping, rape, racism, murder, mutilation, segregation, and torture, in our practices of remembrance. Indeed, acknowledging who we are today requires us to be honest about who we once were. Otherwise, we risk overlooking important facts about ourselves, like the fact that many of our social and economic industries were built on the backs of African and African-American slaves-monsters crushed to earth so that masters could reach the sky!

Indeed, history teaches us that oppression and exploitation are often the human costs of social and economic development. More importantly, however, if we are to avoid repeating the mistakes of our past we must be willing to learn from our history. Towards this end, I offer philosophical analyses of the history of the United States for the purpose of demonstrating that many industries in America thrived on the enslavement, segregation, oppression, and exploitation of "Blacks". Many other scholars have noted this, including David Lightner, Hilary Beckles, and Michelle Alexander. ${ }^{2}$ In fact, some of them have argued for compensatory justice (reparations) as a way of correcting the injustices of the past and ending the injustices of the present ${ }^{3}$. While I believe that many of the calls for compensatory justice have merit, here, I argue that compensation alone is not enough to correct the injustices of the past or end the injustices of the present. Instead, I argue for a five-fold solution that entails compensating the victims of oppression and exploitation, repealing the protections that shield those who engage in oppression and exploitation from criminal and civil responsibility, encouraging "whistle-blowers" to come forward and praising them as advocates of social justice when they do so, developing interpersonal relations between those who are oppressed and exploited and social justice advocates, and utilizing social justice advocates to ensure that our principles of liberty and equality, codes of ethics, and anti-discrimination laws are not violated or sacrificed for economic gains or other reasons. In the end, I conclude with an analysis of how these measures could help us reconceive of the relations between businesses, communities, and individuals so that we can engage in social and economic development and avoid oppression and exploitation in the future.

\section{Cotton Is King: The Monstrosity of American Slavery!4}

The decade prior to the 1860 Presidential election was marked by fierce political disagreement over the institution of slavery. For Republicans, the issue was simple: slavery is contrary to the republicanism on which the country was founded. In fact, Founders like James Madison criticized the plans for establishing the United States from the very beginning, arguing that "where slavery exist the Republican Theory [of government] is all the more fallacious". ${ }^{5}$ In a similar vein, in the original version of the Declaration of Independence, Thomas Jefferson called the institution of slavery "a cruel war against human nature itself". ${ }^{6}$ Those who joined Madison and Jefferson in protests believed that grounding the United States in democratic republicanism meant ending slavery within its borders. After all, republicanism requires adherence to the principles of liberty and equality, and democracy entails that the people are sovereign. On this conception of government, the primary purpose of the social contract is to protect the inalienable rights of individuals from the potential tyranny of majority rule. The Founders attempted to establish protections for individual rights in two ways: first, by embedding the prin-

${ }^{1}$ Coates (2015) Between the World and Me, 70.

${ }^{2}$ David Lightner, and Hilary Beckles offer excellent analyses of the economic significance of slavery to American and British advancement in the 18th and 19th centuries. See Lightner (2006) Slavery and the Commerce Power. London: Yale UP, and Beckles (2013) Britain's Black Debt. Jamaica: University of the West Indies. Additionally, Michelle Alexander offers us a groundbreaking analysis of oppression and exploitation in the American criminal justice system. See Alexander (2012) The New Jim Crow. New York: The New York Press.

${ }^{3}$ For example, see Cose (2004) Bone to Pick. New York: Washington Square Press. Bittker (2003) The Case for Black Reparations. Boston: Beacon Press. Westley (1998) Many Billions Gone: Is It Time to Reconsider the Case for African American Reparations? 19 BC Third World L. Rev. 464, and Fussell (2015) Dead Men Bring No Claims: How Takings Claims Can Provide Redress for Victims of Real Property Takings Owning Victims of Jim Crow Race Riots. William and Mary Law Review. Volume 57, Issue 5.

${ }^{4}$ The phrase "Cotton is King” comes from Abel Thomas’s The Gospel Story of Slavery.

http://www.pbs.org/wnet/african-americans-many-rivers-to-cross/history/why-was-cotton-king/ Also, it is important to note that, in the $19^{\text {th }}$ century, the words Republican and Democrat were used differently from how they are used today. Here, I will be using the $19^{\text {th }}$ century meanings of the terms.

${ }^{5}$ Madison (2006) "Discussion of the Plan" in Founding America Documents from the Revolution to the Bill of Rights, 356.

${ }^{6}$ Jefferson (2006) “Declaration of Independence”, (draft version) in Founding America Documents from the Revolution to the Billof Rights. 
ciples of republicanism in the Preamble to the United States Constitution, and, secondly, by codifying civil liberties in the Constitution in the form of the United States Bill of Rights.

For Democrats, the issue was not one of principle but of law. Article 1, section 9, clause 1 of the United States Constitution allowed Americans to import African slaves into the country—at least until 1808-and Article 4, section 2, clause 3 guaranteed the rights of all Americans to own slaves. This interpretation of the United States Constitution was backed by Congress when it passed the Fugitive Slave Act of 1850, which required states to return runaway slaves to their masters, and prevented states from granting freedom to runaway slaves on the ground that slaves are the property of their masters. In fact, the Supreme Court confirmed these interpretations in its 1856 Dred Scott decision. To be sure, in writing about the status of "Black" people in the United States, Chief Justice Taney tells us that the

Two clauses in the Constitution which point directly and specifically to the Negro race as a separate class of persons, and show clearly that they were not regarded as a portion of the people or citizens of the Government then formed. One of these clauses reserves to each of the thirteen States the right to import slaves until the year $1808 \ldots$.. And the importation which it thus sanctions was unquestionably of persons of the race of which we are speaking, as the traffic in slaves in the United States had always been confined to them. And by the other provision the States pledge themselves to each other to maintain the right of property of the master, by delivering up to him any slave who may have escaped from his service, and be found within their respective territories... And these two provisions show, conclusively, that neither the description of persons therein referred to, nor their descendants, were embraced in any of the other provisions of the Constitution; for certainly these two clauses were not intended to confer on them or their posterity the blessings of liberty, or any of the personal rights so carefully provided for the citizen. ${ }^{7}$

In light of Congress's Fugitive Slave Act and the Supreme Court's Dred Scott decision the South felt vindicated in its interpretation of the US Constitution; and it was ready to fight in order to preserve slavery. After all, the institution of slavery was worth billions. In fact, by 1860, slaves were producing over 2 billion pounds of cotton, much of it was used to supply to $75 \%$ of the world with the raw material necessary for making textiles. But that's not all, slaves also worked as bakers, blacksmiths, bricklayers, butlers, carpenters, carriage drivers, cooks, coopers, concubines, draymen, fishermen, general field hands, hostlers, launderers, masons, maids, millers, nannies, painters, peddlers, porters, seamstresses, stonemasons, stable boys, spinners, sailors, tailors, waiters, and weavers. They therefore produced many different kinds of agricultural crops, including sugar, rice, and tobacco; lumber and other materials for the construction of churches, court houses, homes, jails, municipal buildings, schools, and stores; and other goods such as cookware, utensils, furniture, clothes, and shoes. This made them valuable commodities, i.e. inexpensive to maintain, productive, and most importantly, uncompensated. The table below demonstrates just how valuable slaves were to estates:

\begin{tabular}{|c|c|c|c|c|c|c|}
\hline \multicolumn{7}{|c|}{ Distribution of total estate among slaveholders ${ }^{8}$} \\
\hline Number of slaves & \multicolumn{2}{|c|}{$\begin{array}{c}\text { Total estate } \\
\text { (thousands of } 1860 \text { dollars) }\end{array}$} & \multicolumn{2}{|c|}{$\begin{array}{l}\text { Economic status } \\
\text { (millions of } 2011 \$ \text { ) }\end{array}$} & \multicolumn{2}{|c|}{$\begin{array}{l}\text { Economic power } \\
\text { (millions of } 2011 \text { \$) }\end{array}$} \\
\hline$>1000$ & \multicolumn{2}{|c|}{ NR } & \multicolumn{2}{|c|}{-} & \multicolumn{2}{|c|}{-} \\
\hline 500 - 999 & $\$$ & 957 & $\$$ & 336 & $\$$ & 3320 \\
\hline $100-499$ & $\$$ & 160 & $\$$ & 56 & $\$$ & 555 \\
\hline $50-999$ & $\$$ & 72 & $\$$ & 25 & $\$$ & 250 \\
\hline $10-49$ & $\$$ & 17 & $\$$ & 6 & $\$$ & 59 \\
\hline $5-10$ & $\$$ & 9 & $\$$ & 3 & $\$$ & 31 \\
\hline
\end{tabular}

Of course, the numbers above are staggering but they only represent a small portion of the story because they reflect the worth of slaves to particular estates, not the total worth of slaves. The total worth of slaves is much more astounding. For example, in total, slaves were worth "three times the amount of all monetary investments

\footnotetext{
${ }^{7}$ William Taney's Dred Scott decision. http://www.pbs.org/wgbh/aia/part4/4h2933.html. The Court decided 7-2 against Dred Scott. ${ }^{8}$ This table was produced by Samuel Williamson at the University of Illinois at Chicago and Louis Cain at the Loyola University Chicago. https://www.measuringworth.com/slavery.php.
} 
in American banks"; "three times the value of the livestock population" in the United States; and "twelve times the value of the entire U.S. cotton crop". ${ }^{9}$ In light of these numbers, there can be no doubt that by the middle of the $19^{\text {th }}$ century slavery had become the single most valuable industry in the country. Thus, it is easy to understand why the South was hell-bent on preserving this monstrosity, even if it meant war.

\section{Jim Crow's Country: The Road to Segregation}

\subsection{Colonization}

Of course, Abraham Lincoln did not want a war. In fact, he spent much of his First Inaugural Address attempting to find a balance between northern republicans and southern democrats. Towards this end, Lincoln promised the South that he would not interfere with the institution of slavery, and he reminded the North that he was committed to the Republican Party Platforms of 1860. He writes: "apprehension seems to exist among the people of the Southern States that, by the accession of a Republican Administration, their property and their peace and personal security are to be endangered". ${ }^{10}$ There is no need for this apprehension. For, I am sworn to maintain

the rights of the States, and especially the right of each State to order and control its own domestic institutions according to its own judgment exclusively, which is essential to that balance of power on which the perfection and endurance of our political fabric depend; and we denounce the lawless invasion by armed force of the soil of any State or Territory, no matter what pretext, as among the gravest of crimes. ${ }^{11}$

But, Lincoln's attempts to strike a balance fell on deaf ears. After all, southerners were well aware of all of the Republicans Party Platforms. In fact, generally speaking, they interpreted the Platforms as vilifications of southern Democrats for supporting the dissolution of the Union; condemnations of slave-owners for attempting to extend the institution of slavery into the western territories; and as affirmations of the Jeffersonian Truths that all men are created equal and endowed with the inalienable rights of life, liberty, and the pursuit of happiness. ${ }^{12}$ Thus, for many in the South, the Republican Party Platforms amounted to a "call to war". Therefore, it is not surprising that after Lincoln was elected President, South Carolina seceded from the Union and attacked Fort Sumter; nor is it surprising that nine other slave-holding states joined the rebellion, namely Alabama, Arkansas, Georgia, Louisiana, Mississippi, North Carolina, Tennessee, Texas, and Virginia. ${ }^{13}$

After massive losses on both side, the civil war officially ended when General Robert E. Lee surrendered to General Ulysses S. Grant at Appomattox Court House in March of 1865. By the time Lee surrendered, however, the North had already adopted the $13^{\text {th }}$ Amendment to the U.S. Constitution and thereby abolished slavery. This left Northern politicians wondering what to do with the millions of newly freed people. Some argued for colonization. In fact, President Lincoln urged African-Americans to resettle in Liberia or Central America. ${ }^{14}$ But this proposal went nowhere, and it's easy to understand why: neither Congress, nor Abolitionists, nor AfricanAmericans supported it. Congress quickly determined that transporting millions of African-Americans to another country would cost hundreds of millions of dollars, money the country did not have after the war. Moreover, abolitionists like William Lloyd Garrison openly criticized Lincoln's proposal as "an absurd and preposterous scheme" to abdicate the country's moral responsibility for having made billions of dollars off the unrequited toll of enslaved "Blacks". ${ }^{15}$ Even more, after living, working, fighting, and dying in the United States for over two centuries, Africans-Americans saw themselves as United States citizens, deserving of all of the rights and liberties guaranteed by the U.S. Constitution. After all, America was their country. They helped to build it and after the war they were ready to participate in its social, political, and economic institutions. For these reasons, Lincoln's proposal never gained support.

\footnotetext{
${ }^{9}$ Ibid. Additionally, many scholars offer excellent analyses of the politics, economics, and sociology of slavery. For example, see Wright (2006) Slavery and American Economic Development. LSU Press. Oakes (1982) The Ruling Race: History of American Slaveholders. New York: Knopf, and Johnson (2004) The Chattel Principle. New Haven: Yale U.P.

${ }^{10}$ President Abraham Lincoln. (1861). First Inaugural Address. http://www.bartleby.com/124/pres31.html.

${ }^{11}$ Ibid.

${ }^{12}$ http://www.presidency.ucsb.edu/ws/?pid=29620. The phrase “Jeffersonian Truths” is a reference to the United States Declaration of Independence. The phrase "a more perfect Union" is a reference to the Preamble to the United States Constitution.

${ }^{13}$ Note: The Confederate States of America was not recognized by any foreign nation.

${ }^{14}$ Syrett (2005) The Civil War Confiscation Acts, 56.

${ }^{15}$ Ibid., 45 .
} 
Sojourner Truth's proposal called for giving African-Americans federal grants of land and allowing them to populate sections of the West. Indeed, as the West was being populated by European-American pioneers who received federal land grants, Sojourner Truth realized that westward expansion was an opportunity for African-Americans to become industrious and self-reliant. She immediately formulated a plan and began campaigning "for... a grant of land to be set apart for the freed people to earn their living on". ${ }^{16}$ She raised money, rallied support, collected signatures, offered public addresses, and presented her idea to President Ulysses S. Grant and Congress in 1870. Unfortunately, however, neither the President nor Congress took her proposal seriously. They invited her to speak, listened patiently, and dismissed her proposal without serious consideration as soon as she left their chambers. Even worse, as Sojourner grew ill and lost the strength to continue lobbying for her proposal, no one took up the cause. As a result, the conversation about colonization faded gradually from the national debate. $^{17}$

\subsection{Confiscation}

Representative Thaddeus Stevens' proposal called for confiscating the property of former slave-owners and distributing it to former slaves. His House Bill 29 required 400 million acres of land to be confiscated and distributed in blocks of forty acres "to each [African-American] male... who was the head of a family...; to each [African-American] adult male whether he was the head of a family or not...; and to each [African-American] widow who was the head of a family". ${ }^{18}$ Stevens' Bill represented the final chapter in a series of initiatives designed to liberate and empower African-Americans to become industrious and independent of "White" people. The first initiative gained approval when Congressmen (Senators) Lyman Trumbull, Benjamin Wade, Charles Sumner, (Representatives) Thaddeus Stevens, James Ashley, and John Hutchins succeeded in passing the Second Confiscation Act of 1862 which provided for the emancipation of slaves and the confiscation of the property of "any rebel who did not cease aiding the rebellion within sixty days" ${ }^{19}$ Empowered by the Confiscation Act, General Rufus Saxton and Secretary of War Edwin Stanton convinced General William Sherman to issue Special Field Order No. 15, which "set aside the Sea Island and the low country area thirty miles inland from Jacksonville, Florida up to Charleston, South Carolina and granted freedmen [temporary] 'possessory titles' to forty acres each" ${ }^{20}$ This left it to Congress to determine final ownership of all confiscated property at a later date. The second initiative gained approval when Congress passed the Freedmen's Bureau Act of 1865, which gave the union army the power to "allocate forty acres of the property... to each freedman or loyal refugee". ${ }^{21}$ This meant that the 786,000 acres of land confiscated by the army and turned over to the Bureau could be redistributed to former slaves.

Nevertheless, those who supported confiscation faced staunch opposition from the Executive. In fact, President Andrew Johnson only "supported confiscation against leading Confederates; and he did not support it if it meant that freed slaves would obtain property" and become industrious and independent of "Whites". ${ }^{22}$ Rather, Johnson's version of confiscation entailed that the land of former slave-owners would be confiscated and given to "White" southerners who did not act aggressively towards the North. This was perfectly consonant with Johnson's deeply held belief that "former slaves should be landless laborers and below whites" on the social order. ${ }^{23}$ He therefore returned nearly all of the confiscated land to ex-Confederates who agreed to refrain from hostilities against the North. This effectively undermined the work of Congressmen Trumbull, Wade, Sumner, Stevens, Ashley, and Hutchins, and ended all of the initiatives to liberate and empower African-Americans through confiscation.

\subsection{Reconstruction}

But not all was lost. First, northerners were able to get the $14^{\text {th }}$ and $15^{\text {th }}$ Amendments to the United States Constitution passed through Congress despite staunch opposition. This meant that former slaves would become fully

\footnotetext{
${ }^{16}$ Carson (2003) Civil Rights Chronicle, 38.

${ }^{17}$ Sojourner Truth's land grant proposal was reintroduced in the 20th century as part of the debate over reparations for slavery.

${ }^{18}$ Brophy (2006) Reparations Pro and Con, Appendix 2, A Bill (H.R. 29) Relative to Damages Done to Loyal Men, and for Other Purposes [Confiscation] (1867).

${ }^{19}$ Syrett (2005) The Civil War Confiscation Acts, 49.

${ }^{20}$ Ibid., 143.

${ }^{21}$ Ibid., 144.

${ }^{22}$ Ibid., 138.

${ }^{23}$ Ibid.
} 
enfranchised United States citizens_-but not without upheavals. Secondly, although the Freedman's Bureau could not confiscate land and give it to former slaves, it could ensure that former slaves received equal access and opportunity to participate in the social and economic industries of the South; and it did so in a big way. By the early 1870's, the Freedman's Bureau had assisted hundreds of African-Americans in registering to vote, entering public schools, working in public industries, developing their own industries throughout the South, and successfully winning elections to public offices. ${ }^{24}$ And, for a while, it looked like "Blacks" would become selfreliant and independent after all.

However, not everyone was pleased with the reconstruction efforts. While the northerners enjoyed legislative successes in Congress, southerners organized and positioned themselves to regain control of the South, and then they simply waited. Their opportunity came with the disputed presidential election between Rutherford B. Hayes and Samuel Tilden. In short, the dispute concerned whether Hayes or Tilden would be given the electoral votes necessary for winning the election. A Congressional Commission was formed to decide the matter. After some hotly contested debates, the Commission decided that Rutherford B. Hayes would be given the electoral votes. The southern representatives vehemently protested and filibustered in the House as a way of neutralizing the Commission's decision. The northern representatives attempted to overrule the southerners but their efforts were futile. After all, the filibustering southerners were able to bring Congress to a standstill and the U.S. government to a halt. As a way of getting the southerners to accept Rutherford B. Hayes as President and the government working again, the northerners agreed to a compromise that required them to withdraw federal troops from the South, relinquish control of the South to former Confederates, and refrain from interfering in southern affairs, especially insofar as they related to race relations. This was the Compromise of 1877.

\subsection{Exploitation}

What was most problematic about the Compromise of 1877 was that it placed African-Americans under the rule of former Confederates who, in turn, established violent white supremacist organizations like the Klu Klux Klan (KKK) and introduced segregation that undermined the North's attempts to help African-Americans become self-reliant and independent of "Whites". At the height of its popularity the KKK had four million members, many of whom were in local and state policing agencies, political positions, and judicial appointments. This allowed white supremacists to establish and enforce laws that relegated African-Americans to a life of second class citizenship by preventing them from running for public offices, entering public schools, working in certain industries, developing certain industries on their own, or otherwise participating in public life in a meaningful way. Even worse, when African-Americans attempted to organize and resist they were met with intimidation, assassination, and terrorism from white supremacy groups like the Ku Klux Klan. ${ }^{25}$ Simply put, after the Compromise of 1877, "Blacks” were forced to live under Jim Crow segregation. ${ }^{26}$

More importantly, however, segregation left African-Americans vulnerable to institutional exploitation, and many industries in the U.S. took advantage of this situation. The development of HeLa cells is one of the most famous examples of exploitation in the medical industry. ${ }^{27}$ In 1950, Henrietta Lacks, a poor, uneducated, African-American woman, visited Johns Hopkins Hospital because she was experiencing bleeding and pain in her abdomen. Her doctor performed a biopsy and later diagnosed her with cervical cancer. ${ }^{28}$ What Henrietta didn't know was that the doctors at Hopkins often used poor "Black" patients for medical research without their knowledge. ${ }^{29}$ In fact, one of Hopkins' doctors wrote: "Hopkins, with its large indigent Black population, had no dearth of clinical material”. ${ }^{30}$ So, when Dr. Richard TeLinde (Henrietta's doctor) offered Dr. George Gey the opportunity to experiment with Henrietta's tissues he did not bother to ask if Henrietta had consented to be a tissue donor.

Shortly thereafter, Henrietta returned to Hopkins for her cancer treatment. Asshelayun conscious on the oper-

${ }^{24}$ See Middleton (2002) Black Congressmen During Reconstruction. Westport: Greenwood Press, and Du Bois (1998) Black Reconstruction in America 1860-1880. New York: Freedom Press.

${ }^{25}$ Carson (2003) Civil Rights Chronicle, 40. In fact, between 1890 and 1950, over 4,700 African-Americans were tortured and lynched by white mobs. During this time, nearly 200 anti-lynching Bills were introduced in Congress and all of them were rejected.

${ }^{26}$ Many scholars have noted that reconstruction was an unfinished project. For example, see Foner (1988) Reconstruction: America’s Unfinished Revolution. New York: Perennial Classics.

${ }^{27}$ Rebecca Skloot re-tells Henrietta's story in The Immortal Life of Henrietta Lacks.

${ }^{28}$ Skloot (2011) The Immortal Life of Henrietta Lacks, 27.

${ }^{29}$ Ibid.

${ }^{30}$ Ibid., 30 . 
ating table with her feet in stirrups, "Dr. Lawrence Wharton Jr., sat on a stool between her legs, peered inside her, dilated her cervix... picked up a sharp knife and shaved two dime-sized pieces of tissue" from her. ${ }^{31}$ He sent the tissues to Dr. Gey's laboratory to be experimented on. Two days later a laboratory technician checked on Dr. Gey's experiment and noticed that Henrietta's cell were living and multiplying rapidly, doubling their numbers every twenty-four hours. This was a major medical breakthrough. In fact, Dr. George Gey had become the first researcher to successfully grow human cells in a dish. The cells were labeled HeLa cells, representing the first two initials of Henrietta Lacks' first and last name. But few people knew that HeLa cells were grown from Henrietta Lacks' tissues because Dr. Gey, Dr. TeLinde, and others at Johns Hopkins intentionally hid this information from the public. In fact, they often used a pseudonym, Helen Lane, when discussing or writing about HeLa cells. ${ }^{32}$

More importantly, the development of HeLa cells was a gold mine for Gey and TeLinde. After all, they discovered a method for packing and shipping HeLa cells to other laboratories and they never had to worry about running out of material because the cells replicated quickly. So, they began drafting plans to grow trillions of HeLa cells to sell to research laboratories around the world. Their first major break came with the polio epidemic in the United States. "In 1952, Jonas Salk announced that he had developed the world's first polio vaccine, but he couldn't begin offering it to children until he had tested it and proved it was safe and effective" ${ }^{33}$ Dr. Gey and William Scherer, a researcher at the National Foundation for Infantile Paralysis, were asked to assemble a team of researchers charged with developing a technique that would allow HeLa cells to be used in experiments to determine if Dr. Salk's polio vaccine worked. They set up a massive operation at the Tuskegee Institute in Alabama and grew trillions of HeLa cells a week. Their efforts paid off: using HeLa cells, they were able to prove that Dr. Salk's polio vaccine was safe and effective.

More importantly, it wasn't long before they were able to eradicate the polio virus in the United States. And this was just the beginning, as demands for Dr. Gey's and Dr. TeLinde's cells and laboratory techniques grew, they shipped their research and cells to laboratories all over the world. HeLa cells were used in experiments on cell freezing, cell cloning, chromosome testing, radiation poisoning, and a battery of other tests. Indeed, much of America's medical industry was built on the research that originated in Dr. Gey's and Dr. TeLinde's laboratories. $^{34}$ This made Gey and TeLinde rich and famous. Meanwhile, the Lacks family knew nothing of the Dr. Gey's and Dr. TeLinde's research, experiments involving HeLa cells, the medical breakthroughs, or any other connection between HeLa cells and Henrietta Lacks. In fact, they did not know that Henrietta's tissues had been taken from her until 1976 when Michael Rogers published an article in Rolling Stone magazine detailing the origin of HeLa cells. Even worse, they received no compensation, only a pithy agreement from the National Institute of Health that gives them control over access to the DNA code for HeLa cells, and a virtually meaningless promise to acknowledge them in all future research that depends on HeLa cells.

I wish that I could say that the Henrietta Lacks case was an isolated incident in America's medical industry. Unfortunately, however, the annals of American medicine are replete with cases of oppression and exploitation of African-Americans. In fact, during the same time that Gey and Scherer were growing trillions of HeLa cells, another research group at the Tuskegee Institute was conducting syphilis experiments on African-American men. ${ }^{35}$ Like Gey and TeLinde, the Tuskegee syphilis researchers never disclosed what they were doing or secured the consent of their "research subjects". What's worse is that they often performed painful experiments on their subjects, and they refused to cure them even after they learned that penicillin was an effective remedy for syphilis. The rationale for this was simply that they gained "valuable" information about the long term effects of untreated syphilis in humans - of course, they also gained valuable information that help created the vaccines that are now sold on the market to treat sexually transmitted infections. Other medical experiments were also being conducted on African-Americans during the same time-frame. For example, the practice of sterilizing African-American women was common from the 1930's through the1980's. In fact, it was so common, particularly in the South, that one survey conducted in Sunflower County, Mississippi revealed that "at least $60 \%$ of the African-American women suffered postpartum hysterectomies” without their knowledge or consent. ${ }^{36}$

Of course, oppression and exploitation of African-Americans were not limited to the medical industry. In fact,

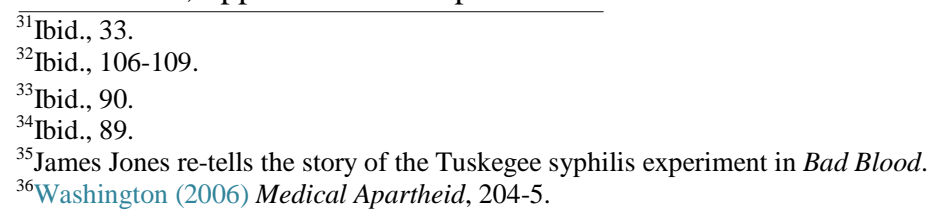


we find oppression and exploitation of "Blacks" in many industries throughout the country, both before and after the Brown v. Board of Education decision, the passage of the $14^{\text {th }}$ Amendment to the U.S. Constitution, and the signing of the Civil Rights Act of 1964, all of which were intended to outlaw Jim Crow segregation. ${ }^{37}$ To be sure, in 2015, the U.S. House of Representatives commissioned a federal investigation of anti-drug taskforces in Alabama, Arkansas, Georgia, Kentucky, Massachusetts, Missouri, New York, Ohio, Texas, and Wisconsinand found that they were guilty of perpetuating racial discrimination and civil rights abuses against African-Americans, including "falsifying records, fabricating evidence, false imprisonment, and indiscriminate round-ups and arrests". ${ }^{38}$

Moreover, such false arrests and convictions translate into large profits for private prisons (private corporations) because many states pay private prisons to house their criminals. Moreover, some states allow private corporations to establish manufacturing operations inside of prisons and hire inmates as cheap sources of labor. In fact, "IBM, Boeing, Motorola, Microsoft, AT \& T, Wireless, Texas Instrument, Dell, Compaq, Honeywell, Hewlett-Packard, Nortel, Lucent Technologies, 3Com, Intel, Northern Telecom, TWA, Nordstrom's, Revlon, Macy's, Pierre Cardin, and Target” have all established operations inside of public and private prisons. ${ }^{39}$ As a result, "their profits have gone up from $\$ 392$ million to $\$ 1.31$ billion". ${ }^{40}$ This is because private corporations pay prisoners a fraction of what they would have to pay workers who are not incarcerated. Additionally, given the over-policing in African-American communities, false arrests and convictions, and the high rates of incarceration of "Black" males, Michelle Alexander and others have argued that America's prison industry is simply segregation reborn in the $21^{\text {st }}$ century. I believe that their conclusions are correct. Even more, I believe that private industries take advantage of this situation by exploiting prisoners, many of whom are "Black", as cheap sources of labor for the purpose of boosting their profits.

\section{Law and the Human Cost of Social and Economic Development: The $21^{\text {st }}$ Century}

My point, in part, is that when we examine the history of America we find that many industries have thrived on the oppression and exploitation of African-Americans. Of course, many politicians, lawyers, professors, and social justice advocates have offered similar critics of American oppression and exploitation. In fact, some have argued for compensatory justice (reparations) as a way of correcting the injustices of the past and ending the injustices of the present. To be sure, U.S. Representative John Conyers, Representative Chaka Fattah, Representative Julia Carson, Professor Charles Ogletree, Professor Robert Westley, Boris Bittker, and Melissa Fussell have all offered justifications for compensatory justice. ${ }^{41}$ And they are not alone. In fact, the demands for compensatory justice from countries like the United States have gone global. In 2001, at the United Nations World Conference against Racism, Discrimination, Xenophobia, and Related Intolerance at Durban, representatives from Human Rights Watch argued that "slavery, the slave trade, and genocide—-the most severe forms of racism associated with the European colonial project, as well as subsequent racist practices of segregation and apartheid-were human rights violations of a criminal nature that should be settled by way of an effective reparations strategy". ${ }^{42}$ I think their call for compensatory justice has merit. In fact, elsewhere, I have argued in favor of compensatory justice.

More importantly, however, I also believe that compensation alone is not enough to correct the injustices of the past or end the injustices of the present. After all, as my analysis above demonstrates, the problems of oppression and exploitation result from complex networks of legal, political, and economic institutions which work

\footnotetext{
${ }^{37}$ Ann Cudd, David Cole, Joe Feagin, Charles Mills, Michael Owen, Cornell West, Melvin Oliver and Thomas Shapiro have offered in-depth analyses of these problems. For example, see Cudd (2006) Analyzing Oppression. Oxford: Oxford U.P. Cole (1999) No Equal Justice. New York: New York Press. Feagin (2000) Racist America. New York: Routledge. Mills (1997) The Racial Contract. Ithaca: Cornell U.P. Owen (2007) God and Government in the Ghetto. Chicago: University of Chicago Press. West (1994) Race Matters. New York: Random House. Oliver and Shapiro (2006) Black Wealth/White Wealth. New York: Taylor and Francis Group.

${ }^{38}$ See H.R. 46, Section 2, Findings of Congress. https://www.congress.gov/bill/114th-congress/house-bill/46/text.

${ }^{39} \mathrm{http} / / /$ www.globalresearch.ca/the-prison-industry-in-the-united-states-big-business-or-a-new-form-of-slavery/8289.

${ }^{40}$ Ibid.

${ }^{41}$ See Slavery Study Bill, H.R. 40, 106th Congress 1st Session (1999), Ogletree (2003) Reparations for the Children of Slaves: Litigating the Issues, 33 U. Mem. L. Rev. 245, 261. Westley (1998) Many Billions Gone: Is It Time to Reconsider the Case for African American Reparations? 19 BC Third World L. Rev. 464. Bittker (2003) The Case for Black Reparations. Boston: Beacon Press, and Fussell (2015) Dead Men Bring No Claims: "Dead Men Bring No Claims: How Takings Claims Can Provide Redress For Real Property Takings Owing Victims of Jim Crow Race Riots.” William and Mary Law Review. Volume 57, Issue 5.

${ }^{42}$ McD. Beckles (2013) Britain’s Black Debt, 185.
} 
in tandem with one another to establish and reinforce discrimination. Indeed, slavery and segregation were established by U.S. legislatures, adjudicated in the Supreme Court, and backed by the coercive powers of state and federal executives. The Fugitive Slave Act and Dred Scott ruling are examples of this. Moreover, once such institutions are established they allow those in the privileged group, in this case European-Americans, to oppress and exploit those in the disenfranchised group, in this case African-Americans, often with impunity. My analyses of the Henrietta Lacks case at Johns Hopkins, the syphilis experiments at Tuskegee, the forced sterilizations throughout the country, and police brutality and racial discrimination throughout the country are examples of this. Compensation alone cannot remedy these problems.

Of course, the United States Congress has passed many laws designed to dismantle institutional oppression and exploitation. In fact, I highlighted some of them above when I discussed the $13^{\text {th }}$ and $14^{\text {th }}$ Amendments to the U.S. Constitution, the Civil Rights Act of 1964, and the Voting Rights Act of 1965. Moreover, many industries in the United States have adopted codes of ethics designed to govern the behaviors of those working within their fields of employment. Additionally, many industries have established ethics review boards to adjudicate breaches of professional ethics. Even more, the U.S. government has used its laws and codes of ethics to condemn perpetrators and compensate many of the victims of oppression and exploitation. For example, "in December 1974, the U.S. government agreed to pay approximately 10 million dollars in an out-of-court settlement” to the victims of the Tuskegee syphilis experiment. ${ }^{43}$ Also, "the U.S. government agreed to the continuation of its ongoing medical and burial programs and it promised to use its 'best' efforts to help locate the men and their heirs". 44

However, what's wrong with only offering compensation to the victims and their families is that the administrators and doctors who participated in the Henrietta Lacks experiments at John Hopkins Hospital, the syphilis experiments at Tuskegee, the forced sterilizations in Mississippi, and the administrators and policemen and women who participated in brutality and racial discrimination throughout the country, were not held criminally responsible for their actions. In fact, in the cases I have discussed above, no one was arrested, charged with a crime, convicted, or sent to jail. Moreover, since the compensation that went to the victims and their heirs came from the coffers of the federal government, the administrators, doctors, and policemen and women were not held civilly responsible for their actions. This is problematic because, even in the cases in which the victims received compensation, those who engaged in oppression and exploitation were not held criminally or civilly responsible for their actions. In which case, they avoided punishment and therefore had no motivations to refrain from engaging in similar behavior in the future.

To correct this problem, state and federal legislatures must back their laws and codes of ethics with teeth, i.e. substantial individual criminal and civil penalties for those who engage in oppression and exploitation. Conversely, state and federal legislatures must repeal the protections that shield those who engage in oppression and exploitation from criminal and civil responsibility. Moreover, state and federal legislatures must strengthen protections for those who engage in "whistle-blowing". In fact, instead of stigmatizing those who come forward as "whistle-blowers", state and federal legislature sought to encourage people to come forward, recognize them as courageous and praise them as advocates for social justice when they do so. This will allow us to develop and strengthen interpersonal relations between those who are oppressed and exploited and those who recognize that oppression and exploitation are wrong and wish to act to stop it in their communities and places of employment. In this way, our social justice advocates will help to ensure that our principles of liberty and equality, codes of ethics, and anti-discrimination laws are not violated or sacrificed for economic gains or other reasons.

These measures will be effective at stopping many industries from preying upon and exploiting those who are disenfranchised - whether for racist, economic, or other motives. However, they are primarily punitive in nature, and therefore, they cannot achieve the ultimate goal of creating industries in which businesses act as good stewards of the communities in which they exist. To achieve this, we must be willing to reconceive of the relations between our businesses, communities, and individuals. To put it straightforwardly, we must be willing to ground all of our industries in our principles of liberty and equality, codes of ethics, and our laws that are designed to protect the individual rights and community standards. In which case, all industries must have the public welfare, not economic gain, at the core of its mission. So, instead of drawing distinctions between for-profit corporations which focus primarily on making money for their shareholders and not-for-profit charitable corporations which focus primarily on providing beneficial services to the communities in which they operate, we might require that

\footnotetext{
${ }^{43}$ Jones (1993). Bad Blood, 217.

${ }^{44}$ Ibid. Ital. mine.
} 
all corporations provide beneficial services to the communities in which they operate, and provide positive benefits to their stakeholders. We have reasons to do this because corporations often receive tax breaks, tax exemptions, subsidies, and other benefits from the communities in which they exist. In return, they should be required to be good stewards of the communities in which they exist. Such industries will be much more likely to create collaborations between themselves, communities, and individuals in which the collective good is at the heart of their businesses. When we reorganize our relations in this way, American industries will be in a position to engage in social and economic development that avoids oppression and exploitation in the future.

\section{Conclusion}

In conclusion, I have offered philosophical analyses of the history of the United States for the purpose of demonstrating that many industries in America have thrived on the enslavement, segregation, oppression, and exploitation of "Blacks". I have argued that neither compensation nor laws, or the combination of compensation and laws are sufficient for correcting the injustices of the past or ending the injustices of the present. For these reason, I have argued in favor of a five-fold solution requiring us to compensate the victims and their heirs, repeal the protections that shield those who engage in oppression and exploitation from criminal and civil responsibility, encourage people to come forward and praise them as advocates for social justice when they do so, develop interpersonal relations between those who are oppressed and social justice advocates, and utilize social justice advocates to ensure that our principles of liberty and equality, codes of ethics, and anti-discrimination laws are not violated or sacrificed for economic gains or other reasons. I have concluded that in order to avoid repeating the mistakes of the past we will need to utilize compensation, laws, social justice advocates, and reconceive of the relations between our businesses, communities, and individuals. Most importantly, I have concluded that this will place us in the position of engaging in social and economic development that avoids oppression and exploitation.

\section{References}

Alexander, M. (2012). The New Jim Crow. New York: The New York Press.

Bittker, B. (2003). The Case for Black Reparations. Boston: Beacon Press.

Brophy, A. (2006). Reparations Pro and Con. Oxford: Oxford U.P.

Carson, C. (2003). Civil Rights Chronicle: The African-American Struggle for Freedom. Lincolnwood: Publications International.

Coates, T.-N. (2015). Between the World and Me. New York: Spiegal \& Grau.

Cole, D. (1999). No Equal Justice. New York: New York Press.

Cose, E. (2004). Bone to Pick. New York: Washington Square Press.

Cudd, A. (2006). Analyzing Oppression. Oxford: Oxford U.P. http://dx.doi.org/10.1093/0195187431.001.0001

Du Bois, W. E. B. (1998). Black Reconstruction in America 1860-1880. New York: Freedom Press.

Feagin, J. (2000). Racist America. New York: Routledge.

Foner, E. (1988). Reconstruction: America's Unfinished Revolution. New York: Perennial Classics.

Fussell, M. (2015). Dead Men Bring No Claims: How Takings Claims Can Provide Redress for Victims of Real Property Takings Owning Victims of Jim Crow Race Riots. William and Mary Law Review, 57.

Jefferson, T. (2006). Declaration of Independence (Draft Version) in Founding America Documents from the Revolution to the Bill of Rights. New York: Barnes and Nobles Classics.

Johnson, W. (2004). The Chattel Principle. New Haven: Yale U.P.

Jones, J. (1993). Bad Blood. New York: Free Press.

Lightner, D. (2006). Slavery and the Commerce Power. London: Yale UP. http://dx.doi.org/10.12987/yale/9780300114706.001.0001

Madison, J. (2006). Discussion of the Plan in Founding America Documents from the Revolution to the Bill of Rights. New York: Barnes and Nobles Classics.

McD. Beckles, H. (2013). Britain’s Black Debt. Jamaica: University of the West Indies.

Middleton, S. (2002). Black Congressmen during Reconstruction. Westport: Greenwood Press.

Mills, C. (1997). The Racial Contract. Ithaca: Cornell U.P. 
Oakes, J. (1982). The Ruling Race: History of American Slaveholders. New York: Knopf.

Ogletree, C. J. (2003). Reparations for the Children of Slaves: Litigating the Issues. 33 U. Mem. L. Rev. $245,261$.

Oliver, M., \& Shapiro, T. (2006). Black Wealth/White Wealth. New York: Taylor and Francis Group.

Owen, M. (2007). God and Government in the Ghetto. Chicago: University of Chicago Press. http://dx.doi.org/10.7208/chicago/9780226642086.001.0001

Skloot, R. (2011). The Immortal Life of Henrietta Lacks. New York: Random House.

Syrett, J. (2005). The Civil War Confiscation Acts. New York: Fordham University Press. http://dx.doi.org/10.5422/fordham/9780823224890.001.0001

Washington, H. (2006). Medical Apartheid. New York: Random House.

West, C. (1994). Race Matters. New York: Random House.

Westley, R. (1998). Many Billions Gone: Is It Time to Reconsider the Case for African American Reparations? 19 BC Third World L. Rev. 464.

Wright, G. (2006). Slavery and American Economic Development. LSU Press.

Submit or recommend next manuscript to SCIRP and we will provide best service for you:

Accepting pre-submission inquiries through Email, Facebook, Linkedin, Twitter, etc A wide selection of journals (inclusive of 9 subjects, more than 200 journals)

Providing a 24-hour high-quality service

User-friendly online submission system

Fair and swift peer-review system

Efficient typesetting and proofreading procedure

Display of the result of downloads and visits, as well as the number of cited articles

Maximum dissemination of your research work

Submit your manuscript at: http://papersubmission.scirp.org/ 